of the non-restraint system), of a case, in which, for some unexplained cause, restraint is not permitted, although restraints, as he previously shows, are again introduced, and in general use, at Lincoln; and calls this case an illustration of the necessity of restraints. If this case, as stated, illustrates anything, it is the wretched condition of the Lincoln Asylum and the party spirit with which the journal is kept; and if his letter illustrate the necessity of restraint at all, it illustrates its necessity by two hundred and fifty-seven instances, not by one. Mr. Hadwen speaks of a retrograde movement at Lincoln. I think the retrograde movement is since April 23, 1840. At all events, Mr. Hadwen's letter is a powerfol illustration of the impracticability of carrying on the non-restraint system, if there be not unanimity amongst the officers of the establishment. May Lincoln be the only asylum in which the interests of humanity are defeated, and chains and fetters riveted on the insane by discord and divisions.

\section{QUACK ADVERTISEMENTS.}

\section{To the Editor of THE LANCET.}

Srr:-In consequence of the selection with which you have honoured Mr. Malyn and myself, I do not hesitate to accept your challenge, although $I$ confess that this sort of correspondence, like the paper skirmishes which have of late crowded the columns of our journals, is very much against my will and taste.

I beg, however, that you will not consider my present letter as any thing like a vindication; indeed, I cannot believe that the reflectiog members of our profession, among whom I, of course, include yourself, can either read the names which you have copied, and suppose that those honourable men who bear them would for a moment so far condescend, o* seriously consider the advertisement of $\mathrm{Mr}$. Thomas Holloway, but as one of those cunning and unauthorised adoptions of abstract passages of letters so much in fashion among the empirics of the day. Your Journal, however, in consequence of its acknowledged spirit and energy, is so much in the hands of other than professional readers, that some allusion to the question of this nostrum may, perhaps, be essential.

There was a Signor Albinolo, of Turin, who came to England with a recipe for this ointment, and, as I afterwards learned, Mr". Holloway, for certain profits, was to find the gold for the purchase and composition of the miraculous salve. Albinolo, a man of seeming simplicity, was confident of the superiority of his ointment, of which he brought me a cargo, requesting me to test its virtues in cutaneous diseases, which I had, of course, no hesitation in doing, although grease is not my favourite vehicle for endermic remedies. This was followed up by entreaties for certificates of its effi. cacy, and if $m y$ note, in answer to these en. treaties and addressed to Albinolo, be published entire, it will be seen that my opiniou was completely decisive as to its want of claim to my adoption; if I remember right, a deprecatory letter from Sir Benjamin Brodie appeared at this time in the "Gazette." A schism now arose between the parties, and statements were inflicted on me by both, but, as a court of law came to a decision on tho subject, it is not essential for me to state on which side the injustice lay. In order, however, to render the cosmetic empiric as little injurious to the credulous public as possible, I took the trouble of cautioning him in a note on the danger of his practices, and there $I$ left the question altogether.

But, Sir, there are deeper causes for the success of empiricism than these garbled extracts of letters, one of which is the sale of nostra by members of the college and licentiates of the ball, who, while in the daily commission of this degrading traffic, hold up their hands, forsooth, for medical reform, and have their names enrolled as members of an association. One source of this unhappy custom has been the facility of professional admission which leads to professional degradation; for many a short-sighted parent is hence induced to make a doctor of his son, and then send him forth almost pennyless into the world, where, to avoid. starvation or servile bondage, he dwindles at once into a petty trader, advancing even his empirical enemy by the sale of that very nostrum which is at once poison to the stomachs of his patients and to his own professional interests; the high curriculum may, probably, in the end amend this in some degree. I believe the public are becoming more alive to the arts and forgeries of the empiric, but while we see pink sancers and blue light as well in the windows of the surgeon as of the druggist, and these doctors' shops are estimated, not according to the quality of their masters' brains, but the bril. liancy of the colours in their show bottles; while a member of the college sells a blue pill at his counter for a penny, and retails even quackery for a most paltry profit; and, above all, while a licentiate, of Pall-Mall East, meets a druggist in consultation, it were vain, indeed, to expect the public to discriminate between professional gentlemen and professional tradesmen.

It is very easy to say how the abolition of all these corrupt modes of low practice and quackery may be ensured, if the profession were true to itself, and not blinded by jealousies to its own interests and honour; it is not by a call on its members for expla. nation-not even by the mere establishment 
of the representative system of professional goverument, unless the council be vested with absolute legislative power, which may define the true line of professional distinc. tion, by the abolition of the counter of the surgeon, and a penal statute, if the chemist shall presume to cross the threshold-stone of the profession; for thus only, however despotic it may seem, can the important dis tinction be established.

And as to empiricism, my own counsel would be the scientific analysis and specification of every nostrum, and the subsequent purchase and promulgation of the secret, by government, of all which might conduce to the health and comfort of mankind, with an interdiction of all others; but this may be a vision of utopia to this liberal age.

In its default, you will do, Sir, more essential service to the profession than even your most judicious comments can confer, if (after having quietly inurned Mr. Warburton's epicene abortion, which, like a blighted foetus, has destroyed the hopes even of his admirers,) you will press on the Chancellor of the Exchequer the necessity of withdrawing the patronage with which he fosters the quacks, in return for the $\mathbf{£ 0 , 0 0 0}$ per annum, which the stamps and advertisements fling into his impoverished treasury. I am, Sir, your obedient servant,

Stamford-street, Oct. 13, 1840. Walter C. Dendy.

EAST LONDON FEMALES' DISPENSARY \& LYING.IN INSTITUTION.

To the Editor of THE LANCET.

SIR:-In some editorial remarks which you have appended to a letter from $\mathrm{Mr}$. Cory, published in the last Number of TuE LANCET, there occurs the following sentence: "For our own part, we should hold such institutions as the East, West, North, and South London Lying-in Institutions in the most sovereign contempt, did we not find reason too of ten to regard them as dangerous and hypocritical both to patients and the public; and we never see the name of a physician professing claims to respectability and reputation, - such as Dr. Francis H. Ramsbotham may think himself entitled to put forth,-attached to the circulars and advertisements of these adventurous establishments, without a feeling of regret on behalf of the good name and welfare of the profession."

If these remarks are intended to apply to the East London Females' Dispensary and Lying-in Institution, situated in Mile-EndRoad, the only charity bearing a title of that kind with which my name is associated, you have formed an erroneous estimate of its character. It has been established very nearly twenty years; it has been supported by some of the most influential people in the neighbourhood, and it is calcnlated to afford considerable benefit to many poor women, who, from their peculiar complaints, shrink from taking the advantages of a hospital,-at least as out-patients, -in con. sequence of the publicity which is inseparably connected with such an application. $I$ acted as superintending physician for more than 12 years, and on my resignation Mr. Cory was appointed; at the same time, the committee paid me the compliment, very usual in such cases, I believe, of retaining my name on the ticket, as consulting physician. The modest character of the institution,-it being held in a private house, the residence of the non-medical secretary, and there being no board or other sign displayed to point out its locality,-is surely no proof of its being either adventurous, or a vehicle for advertising.

No one can be more opposed than I am to the quackery attached to the numerous self-styled dispensaries and medical cha. rities which we meet with so often in different parts of the suburbs of London; and no one would take more pains to divest them of their fancied and false importance than I would do; but there are some few charitable institutions, in which relief is given to the poor at their own dwellings, which demand our respect, and which confer much good. In justice to one of such, and to its supporters, I beg the favour of the insertion of these few lines. I am, Sir, your obedient servant,

Francis H. Ramsbotham.

14, New Broad-street, October 12, 1810.

\section{DR. MAUNSELL AND PROFESSOR BRADY.}

To the Editor of The Lancet.

SIR:-I have no doubt your sense of jus. tice will influence you to give insertion in your next number to the accompanying letter. A copy of it was forwarded to Dr. Brady on the day of its date, as my reply to his request that $I$ would insert an ex parte statement from him, calculated to affix a stigma upon certain defenceless individuals whose innocence of the crime which, by implication, he lays to their charge, was proved before two tribunals. With respect to the other inaccuracies in the communication of Dr. Brady, published in your Number for Oct. 17, it is not my intention to trouble my. self or your readers by making any remark. I have the honour to be, your obedient ser. vant,

Dublin, Oct. 19, 1840.

H. Maunsell.

"Molesworth-street, Sept. 26, 1840.

"Dear Sir :-I must decline publishing 